\title{
The effect of debt ratio and COVID-19 pandemic on profitability of Vietnam coal mining enterprises
}

\author{
Trang Thu Pham *, Huong Van Ngo, Ha Thuy Thi Le \\ Hanoi University of Mining and Geology, Hanoi, Viet Nam
}

\section{ARTICLE INFO}

Article history:

Received $26^{\text {th }}$ July 2021

Revised 25th Oct. 2021

Accepted $29^{\text {th }}$ Nov. 2021

Keywords:

Asset structure,

COVID-19,

Mining companies,

ROE,

Profitability.

\section{ABSTRACT}

After the restructure of the Vietnam National Coal - Mineral Industries Holding Corporation Limited (Vinacomin) from 2012 to 2015, Vietnamese coal mining enterprises recovered their investment in other industries and focused only on coal mining activities. In the context of competition and lack of resources, Vietnamese coal mining enterprises have two solutions: (1) save costs; (2) using loans to invest in new machinery and equipment to increase productivity. In 2020, coal mining enterprises faced difficulties due to complicated developments of the COVID-19 pandemic, disrupting the socio - economic activities of countries worldwide. The article examines the impact of the debt ratio, asset structure, and COVID-19 pandemic on the profitability of coal mining enterprises. It applies the ordinary least squares $(O L S)$ regression method on data of asset structures, capital structures, ROE of 18 coal mining enterprises from 2015 to 2020. The result showed that the debt ratio and the asset structures of a coal mining enterprise positively impact its profitability. The paper also suggests that borrowing to invest in technology will help coal mining enterprises improve their profitability. And an unexpected result is that during the COVID-19 period, coal mining enterprises have higher profitability than those not affected by the COVID19 pandemic.

Copyright (C) 2021 Hanoi University of Mining and Geology. All rights reserved.

\section{Introduction}

Coal mining enterprises of Vietnam National Coal - Mineral Industries Holding Corporation (Vinacomin) in Quang Ninh province play an important role in the socio - economic development of Quang Ninh province and in that

${ }^{*}$ Corresponding author

E - mail: phamthutrang@humg.edu.vn

DOI: 10.46326/JMES.2021.62(6).10 of the Vietnamese economy. In the restructure of Vinacomin, from 2012 to 2015, coal mining enterprises had to withdraw capital from other industries and focus only on coal mining activities. To increase profitability, Vietnamese coal mining enterprises have two solutions: (1) save costs; (2) using loans to invest in new machinery and equipment to increase productivity. In the period 2015 - 2020, the operation of coal mining enterprises gradually stabilized. Then by 2020, coal mining enterprises have faced difficulties due 
to complicated developments of the COVID-19 pandemic, which disrupts the socio - economic activities of countries around the world.

The article is conducted to examine whether borrowing capital for investment will increase the profitability of coal mining enterprises. In contrast, the debt ratio of these enterprises is always high(about 79\% (Table 1)). In addition, the article also examines the impact of COVID-19 on the profitability of enterprises.

The paper employs the ordinary least squares (OLS) regression method. The samples are collected from finance financial statements of 18 coal mining enterprises of Vinacomin (Figure 1) for six years from 2015 to 2020 . The analysis result will help these enterprises to find an effective solution to improve their profitability.

\section{Literature Review}

\subsection{Profitability}

Profitability refers to the ability to make profits from all business activities of an enterprise. Profitability plays a vital role in the success of a business. Profitability is measured by indicators such as Return on Assets (ROA), Return on total Sales (ROS), Return on Equities (ROE). These are the most common metrics used in research to measure profitability. Sivathaasan et al. (2013) studied the factors affecting the profitability of all manufacturing companies listed on the Colombian and Sri Lankan stock exchanges from 2008 to 2012. In which, the profitability of enterprises is represented by two indicators ROA and ROE. Harris et al. (1991) use ROA, ROE, and ROS criteria to reflect profitability.

The article selects the ROE indicator to reflect profitability because this indicator best reflects the impact of financial leverage on the profitability of enterprises.

Dupont model was invented in the early 20th century. This model mentioned the positive relationship between debt ratio and profitability of enterprises.

\subsection{Dupont model studies the impact of capital structure on return on equity}

According to Dupont analysis, the higher the debt ratio, the higher ROE. Many later studies have proved this. Modigliani \& Miller (1963) indicated that leveraged firms had a higher value than one without the debt because of debt tax shields. Gill et al. (2011) showed that debt ratio on ROA was positive in both the service and manufacturing industries.

$$
\begin{aligned}
R O E=\frac{\text { Profit }}{\text { Equities }} & =\frac{\frac{\text { Profit }}{\text { Total assets }}}{\frac{\text { (Total assets }- \text { Debts })}{\text { Total assets }}} \\
& =\frac{\text { ROA }}{1-\frac{\text { Debts }}{\text { Total assets }}} \\
& =\frac{\text { ROA }}{1-\text { Debt ratio }}
\end{aligned}
$$

In contrast, Stiglitz (1969) presented that if the debt ratio went up, the firm's value would decrease because of the existence of the risk of bankruptcy. Umer (2014) showed that the debt ratio had a negative correlation with profitability. Titman (1988) also confirmed that debt ratio had a negative influence on firms' financial performance. Rajan and Zingales (1995) showed that profitability was negatively correlated with the debt ratio. Omondi \& Muturi (2013) found that the debt ratio had a significant adverse effect on the financial performance

\section{Research Method}

\subsection{Model}

Based on the assumption that coal mining enterprises' capital structures positively affect their return on equity (ROE), the paper identified factors affecting profitability according to the Dupont model. The DuPont Model establishes a connection between ROA, debt ratio, and equity in its most simplistic form. Studying the impacts of capital structure, asset structure and the COVID19 pandemic on ROE, the paper proposes adding the asset structure variable (LTA) and the COVID19 (COVID) dummy variable into the model. (ROE)

- Dependent variable: Return on equity

Return on equity (ROE) is a measure of financial performance calculated by dividing net profit by shareholders' equity. Because share holders' equity is equal to an enterprise's assets minus its debt. ROE is the return on net assets. ROE is considered a measure of how effectively management is using a equity capital to create 
profis.

$$
R O E=\frac{\text { Net Profit }}{\text { Average shareholders' equity }}
$$

- Independent variables: Return on total assets (ROA); Leverage (LEV); Long - term assets ratio (LTA) and the COVID-19 (COVID).

Return on total assets (ROA): Return on total assets is determined by the ratio of the profit after tax in a year to the firm's average assets. This index measures the ability of a firm to use its assets to make profits. Good asset utilization levels will lead to an increase in the firm's profitability.

$$
R O A=\frac{\text { Net Profit }}{\text { Average total Assets }}
$$

Leverage (LEV): The debt ratio is a financial ratio that measures the extent of a company's leverage. Borrowing money provides firms an additional source of capital to operate and an opportunity to get more profit from the difference between the additional revenue and the cost of the capital, leading to an increase in ROE. Most firms are currently using debts as financial leverage to generate profit and divert risks for their owners' investment. The debt ratio is determined by the average liabilities to the firm's average total resources.

$$
L E V=\frac{\text { Average liabilities }}{\text { Average total assets }}
$$

Long - term assets ratio (LTA): The structure of firm assets is measured by the percentage of long - term assets to total assets. In theory,

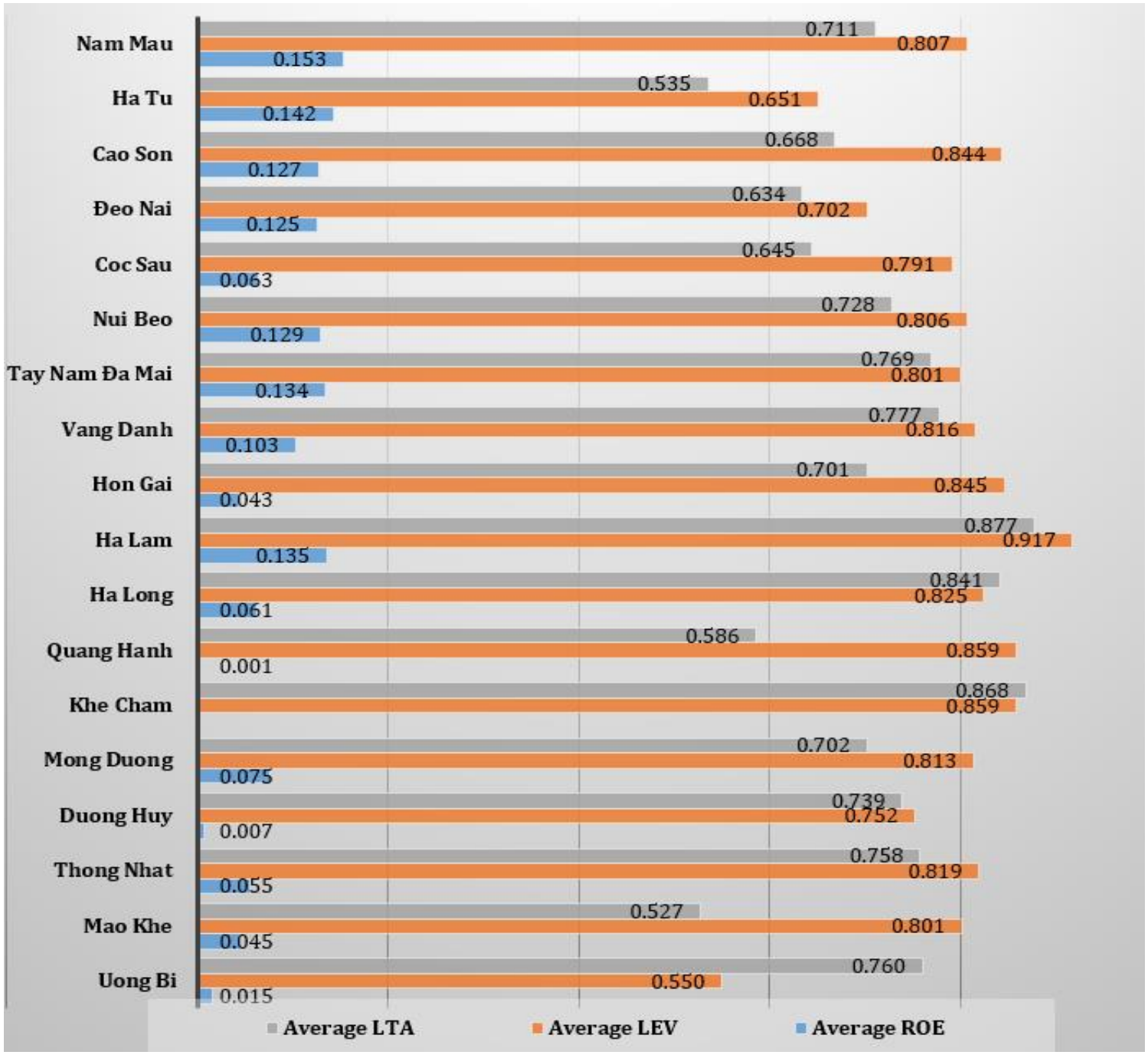

Figure 1. Average ROE, LTA and LEV for the period 2015 2020 . 
companies heavily investing in long - term assets are more efficient in doing business. This paper examines if the investment in long - term assets makes coal mining enterprises more profitable.

$$
\text { LTA }=\frac{\text { Average long }- \text { term assets }}{\text { Average total assets }}
$$

COVID-19 (COVID): The dummy variable was included to study the difference in ROE during the period of the COVID-19 pandemic and the periods without the COVID-19 pandemic. Accordingly, observations during the COVID-19 period received a value of 1 , and the others received a value of 0 .

This study adopted Return on Equity (ROE) as dependent variables for measuring firms' profitbility. In contrast, 4 independent variables are the rate of Return on Assets (ROA), capital structure, debt ratio (LEV), assets structure (LTA), and the COVID-19 (COVID).

The model will be estimated using OLS regression running on IBM SPSS Statistics 20 version as follows:

$$
\begin{aligned}
R O E_{i}=\widehat{\beta_{0}}+ & \widehat{\beta_{1}} \cdot R O A_{i}+\widehat{\beta_{2}} \cdot L E V_{i} \\
& +\widehat{\beta_{3}} \cdot L T A_{i}+\widehat{\beta_{4}} \cdot \text { COVID } \\
& +e_{i}
\end{aligned}
$$

Where: $\left(\beta_{0}\right)$ - intercept coefficient; $\left(\beta_{1}\right),\left(\beta_{2}\right)$, $\left(\beta_{3}\right),\left(\beta_{4}\right)$ - the coefficients indicate the impact of ROA, LEV, LTA, COVID on ROE respectively.

\subsection{Data}

The empirical goal of this research is to investigate the impact of capital structure, asset structure, and COVID-19 pandemic on the profitability of Vinacomin coal mining companies. The secondary data for this research were collected from annual financial reports of 18 coal mining firms of Vinacomin from 2015 to 2020.

Coal mining enterprises belonging to Vinacomin in Quang Ninh include nine companies in which Vinacomin holds $100 \%$ of charter capital and nine joint - stock companies in which Vinacomin has over $50 \%$ of charter capital.

\section{Results and discussion}

\subsection{The research result}

Data were analyzed by using SPSS Statistics for Windows. The results are shown below.

Descriptive statistics show that the mean of the ROE of 18 coal enterprises from 2015 to 2020 is $7.89 \%$, with a standard error of $12.68 \%$. In comparison, that of ROA is relatively low, only $1.7 \%$, with the standard error of $2.65 \%$. The mean of asset structure is $73.87 \%$, with a standard error of $13.7 \%$. An average debt ratio of those enterprises is $78.87 \%$, which is relatively high, with a standard error of $9.92 \%$ (Table 1 ). The descriptive statistics suggest that the efficiency of those enterprises is relatively low, and they are heavily dependent on loans from external sources.

Table 1. Descriptive Statistics.

\begin{tabular}{|c|c|r|c|c|c|}
\hline & $\mathrm{N}$ & \multicolumn{1}{c|}{ Min } & Max & Mean & Std. Dev \\
\hline ROA & 107 & -0.1376 & 0.0935 & 0.0170 & 0.0265 \\
\hline LTA & 107 & 0.3669 & 0.9490 & 0.7387 & 0.1370 \\
\hline LEV & 107 & 0.3765 & 0.9249 & 0.7887 & 0.0992 \\
\hline ROE & 107 & -0.5420 & 0.4333 & 0.0789 & 0.1268 \\
\hline
\end{tabular}

Regression results show that the multiple $\mathrm{R}$ is 93.9\% suggesting that ROA, LEV, LTA, and COVID are valid independent variables. Adjusted R square is $87.6 \%$ which is quite close to the $\mathrm{R}$ square, demonstrating that all the factors are essential. The Durbin - Watson test results in 1.91 $(1<\mathrm{d}<3)$ show that there is no autocorrelation detected in the sample (Table 2).

Table 2. Model Summary.

\begin{tabular}{|c|c|c|c|c|c|}
\hline Model & $\mathrm{R}$ & $\begin{array}{c}\mathrm{R} \\
\text { Square }\end{array}$ & $\begin{array}{c}\text { Adjusted } \\
\text { R Square }\end{array}$ & $\begin{array}{c}\text { Std. Error } \\
\text { of the } \\
\text { estimate }\end{array}$ & $\begin{array}{c}\text { Durbin - } \\
\text { Watson }\end{array}$ \\
\hline 1 & 0.939 & 0.881 & 0.876 & 0.04456 & 1.914 \\
\hline
\end{tabular}

Significance $\mathrm{F}$ is approximately 0 , implying that the linear regression equation cannot be rejected (Table 3 ).

Table 3. ANOVA.

\begin{tabular}{|c|c|c|c|c|c|}
\hline Model & $\begin{array}{c}\text { Sum of } \\
\text { Squares }\end{array}$ & Df & $\begin{array}{c}\text { Mean } \\
\text { Square }\end{array}$ & F & Sig. \\
\hline Regression & 1.501 & 4 & 0.375 & 188.971 & $0.000^{\mathrm{b}}$ \\
\hline Residual & 0.203 & 102 & 0.002 & & \\
\hline Total & 1.703 & 106 & & & \\
\hline
\end{tabular}

The VIF of the variable selected in this model is less than 2, and the model has no collinearity problem. The Sig value of the $t$ - test of each independent variable is less than 0.05 , meaning that these variables are statistically significant 
(Table 4).

Table 4. Coefficients.

\begin{tabular}{|c|c|c|c|c|c|c|c|}
\hline \multirow[t]{2}{*}{ Model } & \multicolumn{2}{|c|}{ 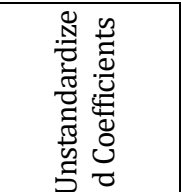 } & 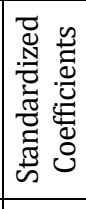 & \multirow[t]{2}{*}{$\mathrm{T}$} & \multirow[t]{2}{*}{ Sig. } & \multicolumn{2}{|c|}{ 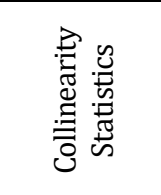 } \\
\hline & B & $\begin{array}{c}\text { Std. } \\
\text { Error }\end{array}$ & Beta & & & 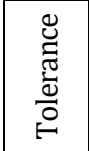 & VIF \\
\hline Constant & -0.285 & 0.043 & & -6.590 & 0.000 & & \\
\hline ROA & 4.807 & 0.180 & 1.000 & 26.741 & 0.000 & 0.827 & 1.209 \\
\hline LTA & 0.136 & 0.041 & 0.147 & 3.285 & 0.001 & 0.586 & 1.707 \\
\hline LEV & 0.225 & 0.048 & 0.176 & 4.713 & 0.000 & 0.836 & 1.196 \\
\hline COVID & 0.029 & 0.014 & 0.083 & 2.099 & 0.038 & 0.742 & 1.347 \\
\hline
\end{tabular}

Therefore, the forecasted model can be rewritten as follows:

$$
\begin{aligned}
R O E i & =-0.285+4.807{ }^{*} R O A i+0.136^{*} L T A i \\
& +0.225 * L E V i+0.029 * \text { COVID }+e i
\end{aligned}
$$

The model reveals that all variables are positively related to ROE. If other factors are fixed, ROA increased by 1 unit, ROE would increase to 4.807. Similarly, ROE increase to $0.136,0.225$ and would be $2.9 \%$ higher than previous years when LTA, LEV increase by 1 , and COVID-19 outbreak in 2020, respectively (Table 4).

To understand the impact of LAT, LEV, and COVID-19 on ROE, we will consider each factor. The debt ratio has a positive effect on the profitability of the business. The result shows that leverage has been used successfully, increasing ROE by Vietnamese coal companies. Asset structure has a positive effect on profitability. This information is entirely consistent with the characteristics of coal companies in Quang Ninh. When mining conditions become challenging, coal enterprises have to invest in modern technology to increase productivity and reduce costs. Enterprises with little investment will have lower productivity and, therefore, lower profitability. The results are entirely consistent. Enterprises with large debt ratios and high long - term assets ratioss are most companies operating with increased profitability, such as Ha Lam, Nam Mau (Figure 1). There are two solutions to increase debt ratios of Vietnamese coal mining enterprises: (1) Using a deferred payment letter of credit for suppliers; and (2) requiring advance payments from buyers.

In 2020, the COVID-19 pandemic occurred, but Vinacomin coal mining enterprises in the Quang Ninh area had higher ROE than previous years. The reasons are: (1) coal export volume increased sharply with high export coal price, thereby increasing profitability at the end of 2020; and (2) coal mining enterprises weree still allowed to operate under strict supervision in the complicated epidemic situation. In addition, VinacoMin coal mining enterprises in Quang Ninh area consistenly earnestly implement epidemic prevention measures, check and monitor workers' health daily, manage schedules and movement of workers, etc.

\subsection{Recommendation}

An effective solution to improve the profitability of Vinacomin's coal mining enterprises is to invest in technology. Enterprises need to invest heavily in the mechanization of production. To ensure practical investment activities, coal mining enterprises of Vinacomin need to have a set of criteria to support the implementation, monitoring, and evaluation of the performance of each technology solution.

To improve profitability on equity, companies must find low - cost loans, such as corporate bonds, preferential loans from banks and financial institutions, credit institutions, etc. Besides, they should continue to take advantage of deferred payment letters of credit for suppliers and require the buyer to pay in advance.

In addition, businesses need to continue to promote and improve their risk management capacity to deal with socio - economic crises, epidemics, natural disasters, etc. to minimize losses from these crises.

\section{Conclusions}

The article uses the regression method to study the impact of capital structure, asset structure, COVID-19 pandemic on ROE. The research samples were collected from the financial statements of 18 coal mining enterprises of Vinacomin for the period of 2015 - 2020. The research result showed that the debt ratio of coal mining enterprises is high and loans to invest plays a vital role in improving the profitability of 
businesses. Because of the excellent control of the COVID-19 epidemic, coal mining enterprises still operate effectively during the period of the covid epidemic. The article also proposes some recommendations to improve the business efficiency of these coal mining companies, which are: (1) borrowing capital to invest in machinery and equipment to improve business efficiency; (2) investing in technology and having a set of criteria to support the implementation, monitoring, and evaluation of each technology solution's performance; (3) find low - cost loans such as corporate bonds, preferential loans from banks and financial institutions, credit institutions, continue to take advantage of deferred payment letters of credit for suppliers and require customers to pay in advance; and (4) continuing to promote and improve their risk management capacity to deal with socio - economic crises, epidemics, natural disasters, etc.

\section{Acknowledgements}

The authors would like to extend their special thanks to Mr. Le Ngoc Toan - General Accountant of Vietnam National Coal - Mineral Industries Holding Corporation - for his help during the study.

\section{Contribution of authors}

Ha Thuy Thi Le wrote part 2. Huong Van Ngo wrote part 5. Trang Thu Pham wrote part 1, 3, and 4.

\section{References}

Gill Amarjit. Nahum Biger \& Neil Mathur, (2011). The effect of capital structure on profitability: Evidence from the United States. International Journal of Management. 28(4).
Harris, M., Raviv, A., (1991). The Theory of Capital Structure. The Journal of Finance, 46, 297 355. https://doi.org/10.1111/j.1540 6261.1991. tb03753.x

Modigliani. F., Miller. M. H. (1963). Corporate Income Taxes and the Cost of Capital: A Correction. The American Economic Review, 53(3). p. 433

Omondi. M. M. \& Muturi. W. (2013). Factors Affecting the Financial Performance of Listed Companies at the Nairobi Securities Exchange in Kenya. Research Journal of Finance and Accounting, 4(15). p.99.

Rajan. R. G.. \& Zingales. L. (1995). What Do We Know about Capital Structure? Some Evidence from International Data. The Journal of Finance, 50(5), p.1421.

Sivathaasan, N. R., Tharanika, M., Sinthuja, V. Hanitha. (2013). Factors determining profitability: A study of selected manufacturing companies listed on Colombo Stock Exchange in Sri Lanka. Tạp chí European Journal of Business and management, 5(27). $99-108$

Titman. S. (1988). The Determinants of Capital Structure Choice. The Journal of Finance, 43(1). p.1.

Stiglitz. J. E. (1969). A Re - Examination of the Modigliani - Miller Theorem. American Economic Review,59(5), p.784.

Umer. U. M. (2014). Determinants of Capital Structure: Empirical Evidence from Large Taxpayer Share Companies in Ethiopia. International Journal of Economics and Finance. 6(1). p.53.

Vinacomin (2021). Financial statements of Coal mining enterprises from 2015 to 2020. 